\title{
Optimal Locations of Facilities for the Elderly in Matsumoto using a Hierarchical Generalized $P$-median Model
}

\author{
Jun YAMASHITA*
}

\begin{abstract}
In the present study, we search optimal locations of two kinds of facilities for physical and mental senile persons: day service centres and short stay homes. The day service centres, which provide various services for senile people in the daytime, are desiable to be located in the neighbourhood so that caretakers easily transport the senile persons to the day service centres. The short stay homes give senile persons advanced care during a short period. Unlike the day service centres, the short stay homes are less likely to be situated in the vicinity of senile persons because the senile persons do not need to commute between the short stay homes and their residence. On account: of differences in the distance-elasticity of demands for day service centres and short stay homes, hierarchical generalized $p$-median model is suited for searching optimal locations of these facilities. In the generalized $p$-problem, optimal locations are identified through minimizing the total travel costs measured by elderly population and time distances in a network in Matsumoto. Both high percentage of elderly people in the total population and high rate of car owners in the total households are the reasons that Matsumoto was selected as the study area. The hierarchical generalized $p$-median problem is solved along two scenarios. In Scenario 1, optimal locations of five short stay homes are found amongst those of 14 day service centres. Scenario 2 is called backup system where locations of five short stay homes are selected amongst places excluding locations of 14 day service centres. Optimal locations of the day service centres derived from Scenarios 1 and 2 are regularly distributed, while those of the short stay homes are randomly distributed. Those optimal locations differ from locations of existing day service centres and short stay homes. We find shortage of those facilities in the central part of Matsumoto. The remote locations of the existing day centres and short stay home compel senile people to travel long. High land price and an image of the facilities for senile persons as a noxious facilities are considered as a reason why both day service centres and short stay homes are located in the fringe of Matsumoto.
\end{abstract}

\section{Introduction}

Heretofore various types of hierarchical deterministic location-allocation models have been developed $^{1}$. In the deterministic models, which also include the central place theory, it is assumed that total population at a demand point is allocated to the nearest facility. This assumption on population assignment is called the nearest allocation rule.

* Graduate School of Geoscience at the University of Tsukuba 
The nearest allocation rule, however, has no validity in explanation on actual consumer behaviour. Some researchers examined the nearest allocation rule using various shopping activities, and concluded that not all consumers patronize nearest retail outlets (Rushton et al., 1967 ; Clark, 1968 ; Clark and Rushton, 1970). Consequently, Wilson and Senior (1974), and Coelho and Wilson (1976) presented a theoretical framework for probabilistic location-allocation models instead of deterministic ones ${ }^{2}$. In the framework, they explicated a relationship between consumers' welfare maximization problem and $p$-median problem, in which optimal locations are specified through minimization of total travel costs under the nearest allocation hypothesis. Thus, the $p$-median problem is regarded as a special case of the consumers' welfare maximization problem when distance-decay parameter of a spatial interaction model in the consumers' welfare maximization model tends to be infinite. However, Hodgson (1981) pointed out little difference in locational configurations derived from the $p$-median and the consumers' welfare maximization problems in his empirical study.

Since Wilson and his associates theoretically demonstrated possibility of overwhelming the failure of the nearest allocation rule, some researchers tackled construction of hierarchical probabilistic location-allocation models for both public and private facilities. Kohsaka (1983) presented a generalized central place model so as to integrate the central place theory by Christaller and Lösch into the realm of hierarchical probabilistic location-allocation models. In his numerical example, he showed relevancy of his hierarchical probabilistic location-allocation model in general situations of population distribution instead of uniform distribution of population assumed in the central place theory. Because his attention was directed to integration of the central place theory into the probabilistic location-allocation models, technically speaking, his model was not probabilistic judging from his introduction of a binary variable which solely allocates total population in a region to a specific central place like a deterministic model ${ }^{3)}$. As the result of introduction of the binary variable, his model is also classified as a quasi-probabilistic model. Using an identical quasi-probabilistic model, O'Kelly and Storbeck (1984) optimized locations of two types of life aid facilities, namely basic and advanced life support units. In a scenario of optimal locations, they considered two levels of a hierarchy where three locations of advanced life support units were selected amongst six locations of basic ones like the Christaller model. However, few hierarchical locationallocation problem is solved in a fully probabilistic mode.

According to Narula (1984, p. 94), hierarchical location-allocation problems are classified into four categories by two disciplines on interactions between nodes. One is arc flow discipline, which also consists of two criteria : integrated (I) and discriminating (D). The integrated flow is a flow connecting any lower level with any higher level. Conversely, the discriminating flow is a flow linking any lower level to the next higher level. The other is node flow discipline comprising two criteria: unipath (U) and multipath (M). The unipath terminates from each node at any lower level to less than and equal to a node at any higher level (one-to-one correspondence). To the contrary, the multipath links each node at any lower level with more than two nodes at the higher level (one-to-many correspondence). By combination of the two disciplines with two criteria each, we obtain the following four 
categories on hierarchial location-allocation problems: I/U location-allocation problems, $\mathrm{I} / \mathrm{M}$ location-allocation problems, $\mathrm{D} / \mathrm{U}$ location-allocation problems, and, D/M locationallocation problems.

The I/M location-allocation problems are applicable for a hierarchical system of facilities for sen:le people in Japan, which consists of day service centres and short stay homes. Day service centre provides various service, like offering meals and a bath, for physical and mental senile persons in the daytime. The day service centres are desirable for senile persons and the:ir caretakers to be located in their neighbourhood because the caretakers are likely to suffer from long travels to the centres with their senile persons. On the other hand, an advanced elderly facility for senile people is short stay home. The short stay homes accommodate senile persons for a while, usually a week, and take care of them in the 24hours supervision. Thus, the day service centres are regarded as elderly care facility at the low level, while the short stay homes are considered as elderly care facilities at the high level in the elderly care system.

As to locations of facilities for the senile persons, administrators of social services for pensioners intended that distance-decay effects on users of elderly facilities are more influential at the low level than at the high level so that the day service centres are scattered in each community in the city, while the elderly service centres are placed in the city centre. The increasing number of households possessing their own cars, however, reinforces mobility of the households with elderly persons so that the nearest allocation rule becomes inappropriate in consideration of optimal locations of facilities for the elderly, while it is also valid to assume that distance-decay effects on the day service centres are stronger than those on the short stay home. Thereby, we shall relax the implicit assumption on the distancedecay parameter and also may consider a hierarchical location-allocation problem in a large variation of the distance-decay parameter. Hierarchical generalized $p$-median models enable us to obtain optimal locations of both the day service centres and short stay homes. The present study, therefore, addresses optimal location of facilities for the elderly with two levels of a hierarchy under variation in the distance-decay parameter.

In the next section, generalized $p$-median model is presented as the framework for this study. In the third section, results of the applications of a hierarchical generalized $p$-median model are shown under change in the distancedecay parameter at both the low and high levels. In the fourth section, we compare optimal locations derived from the hierarchical generalized $p$-median problem with locations of existing facilities. In the last section, some conclusions are drawn.

\section{Methods}

In this section, a hierarchical location-allocation model based on the generalized $p$-median model is presented. We expect different locational configurations derived from variation in distance-decay parameter in the hierarchical location-allocation model. The nearest neighbour measure enables us to identify locational configurations by means of three location patterns.

\section{1) Hierarchical generalized $p$-median} model

Location-allocation problems are solved by minimizing or maximizing an objective function subject to a set of constraints. Heretofore, some geographers have developed various kinds 
of probabilistic location-allocation models incorporating spatial interaction models (Leonardi, 1981 a, b ; O’Kelly, 1987 ; Fotheringham and O'Kelly, 1989). Amongst those models, the travel cost minimization problem is termed $p$-median problem. In the $p$-median model, the nearest allocation rule is originally presumed. Through relaxation of the nearest allocation rule, Beaumont (1980, p. 39) extended the $p$-median problem, and in turn, presented a generalized $p$-median model in plane. An objective function of the generalized $p$-median is formulated as :

$$
\text { Minimize } Z=\text { Minimize } \sum_{i} \sum_{j} S_{i j} \mathrm{c}_{i j}
$$

If the production constrained spatial interaction model represents the interaction or population allocation term $S_{i j}$, the objective function in equation (1) is minimized under the following constraints :

$$
\begin{aligned}
& S_{i j}=A_{i} O_{i} W_{j} \exp ^{\alpha}\left(-\beta d_{i j}\right) \\
& A_{i}=\left[\sum_{j} W_{j}^{\alpha} \exp \left(-\beta d_{i j}\right)\right]^{-1} \\
& O_{i}=\sum_{j} S_{i j} \\
& (i=1,2, \cdots, l ; j=1,2, \cdots, m .)
\end{aligned}
$$

where

$S_{i j}$ : interaction between regions $i$ and $j$,

$c_{i j}$ : travel costs between regions $i$ and $j$,

$A_{i}$ : balancing factor,

$O_{i}$ : total population in region $i$,

$W_{i}$ : attraction term at each facility,

$d_{i j}$ : distance between regions $i$ and $j$,

$\alpha$ : mass parameter,

$\beta$ : distance-decay parameter,

$l:$ the number of regions,

$m$ : the number of facilities, and $l \geq m \geq 0$.

By means of introduction of equation (2), population in region $i$ is probabilistically allocated to each centre in accordance with values of the distance-decay parameter. On the basis of the generalized $p$-median problem in equation (1), a hierarchical form is constructed as follows:

$$
\text { Minimize } \sum_{h} Z^{(h)}=
$$

$$
\text { Minimize } \sum_{h} \sum_{i} \sum_{j} S_{i j}{ }^{(h)} c_{i j}{ }^{(h)}
$$

In this equation, $h$ denotes hierarchical levels.

Both bottom-up and top-down methods can approach optimal solution of this hierarchical generalized $p$-median problem. In this study, the hierarchical $p$-median problem with two levels is solved on the base of the bottom-up method: day service centres at the low level and short stay homes at the high level. Thus. equation (5) is rewritten as :

$$
\begin{aligned}
& \text { Minimize }\left(Z_{L}+Z_{H}\right) \\
& \quad=\operatorname{Minimize}\left(\sum_{i} \sum_{j} S_{i j} c_{i j}+\right. \\
& \left.\quad \sum_{i} \sum_{k} S_{i k} c_{i k}\right)
\end{aligned}
$$

subject to

$$
\begin{aligned}
& S_{i j}=A_{i} O_{i} W_{j}^{\alpha_{L}} \exp \left(-\beta_{L} d_{i j}\right) \\
& S_{i k}=A_{i} O_{i} W_{k}{ }^{\alpha} H \exp \left(-\beta_{H} d_{i k}\right) \\
& A_{i}=\left[\sum_{j} W_{j}{ }^{\alpha} \exp \left(-\beta_{L} d_{i j}\right)\right]^{-1} \\
&=\left[\sum_{k} W_{k}{ }^{\alpha} H \exp \left(-\beta_{H} d_{i k}\right)\right]^{-1} \\
& O_{i}=\sum_{j} S_{i j}=\sum_{k} S_{i k} \\
&(i=1,2, \cdots, l ; \quad j=1,2, \cdots, m ; \quad k=1, \\
&2, \cdots, n ; l \geq m \geq n \geq 0)
\end{aligned}
$$

where

$Z_{L}$ : total travel costs at the low level, $Z_{H}$ : total travel costs at the high level, $S_{i j}, S_{i k}$ : interactions between regions $i$ and $j$, and regions $i$ and $k$, respectively, $c_{i j}, c_{i k}$ : travel costs between regions $i$ and $j$, and regions $i$ and $k$, respectively,

$A_{i}$ : balancing factors in region $i$,

$O_{i}$ : total population in region $i$,

$W_{j}, W_{k}$ : attraction terms at facilities $j$ and $k$, respectively,

$d_{i j}, d_{i k}$ : distances between regions $i$ and $j$, and regions $i$ and $k$, respectively, $\alpha_{L}, \alpha_{H}:$ mass parameters at the low and high levels, respectively,

$\beta_{L}, \beta_{H}$ : distance-decay parameters at the low and high levels, respectively,

$l:$ the number of demand points,

$m$ : the number of facilities at the low level, 
$n:$ the number of facilities at the high levvel.

The objective function in equation (6) was solved in three cases of the distance-decay parameter: 1.5, 0.15 and 0.015. Hodgson (1978) revealed a similarity in population allocation between a deterministic location-allocation problem and a probabilistic one with a distance-decay parameter of 1.5 in his simulation study. Besides, Yamashita (1993) examined patronage of pensioners to daycentres in Malmö, Sweden. In his article, he concluded that no: all pensioners patronize nearest daycentres and that distance elasticity of trips to daycentres is moderate: the distance-decay parameter indicates approximately 0.15 . According to Fotheringham and O'Kelly (1989, pp. 151-157), facility locations are decentralized in a probabilistic location-allocation model with the distance-decay parameter of 0.2 , while clustered in that with the distance-decay parameter of 0.025 . This is the reason why the distance decay parameter of 0.015 was selected as a representative of the smallest distancedecay parameter.

Maturnoto in the middle Japan was selected as the study area (Fig. 1). The rate of elderly population within the total population in this city (14.8 percent in 1992) was higher than the average in Japan (12.5 percent). Moreover, the number of car owners within 1,000 persons, which enhances access to the elderly care facilities, was higher in Matumoto (315.4 cars in 1991) than the average in Japan (298.7 cars). Those characteristics led to select the city as the study area.

This study intends to obtain a set of optimal location:s which is purely affected by the spatial interaction. In other words, our attention should be directed to solitary effects of the distance-decay parameter on locations of facili-

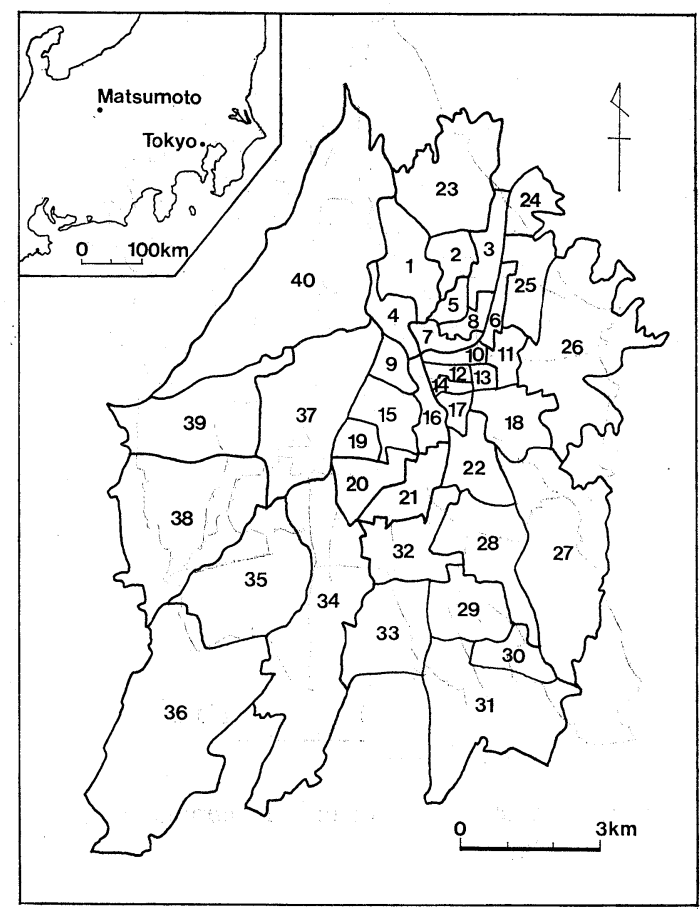

Fig. 1 Study area

1. Arigasaki, 2. Sawamura, 3. Asahi, 4. Miyabuchi, 5. Kaichi, 6. Motomachi, 7. Ohte, 8. Metoba, 9. Nagisa, 10. Chuo, 11. Agata, 12. Fukashi, 13. Uzuhashi, 14. Honjyo, 15. Soyano, 16. Igawajyo, 17. Syonai, 18. Tsukama, 19. Sasabe, 20. Minamihara, 21. Minami matsumoto, 22. Idegawamachi, 23. Okadamachi, 24. Asama onsen, 25. Ohmura, 26. Satoyamabe, 27. Nakayama, 28. Kotobuki sirasebuchi, 29. Kotobuki toyooka, 30. Kotobukidai, 31. Uchida, 32. Yoshikawa nomizo, 33. Yoshikawa muraimachi, 34. Sasaga, 35. Kanbayashi, 36. Imai, 37. Shimadachi, 38. Wada, 39. Niimura, 40. Shimauchi

ties. To this purpose, mass parameters $\left(\alpha_{L}\right.$ and $\left.\alpha_{H}\right)$ were fixed at one $\mathrm{e}^{4)}$. Besides, attraction terms were given the same figures to each facility, namely $W_{j}=\left[\left(\sum_{i} \sum_{j} S_{i j}\right) / m\right]$ and $W_{k}=\left[\left(\sum_{i} \sum_{k}\right.\right.$ $\left.S_{i k}\right) / n$ ], because the mass parameters were fixed at one.

Population data were gathered in Matsumoto, which comprises 40 regions. In this study area, population term $\left(O_{i}\right)$ was measured by elderly population in each region, and the total elderly population $\left(\sum_{i} O_{i}\right)$ is $26,674^{5)}$. This 


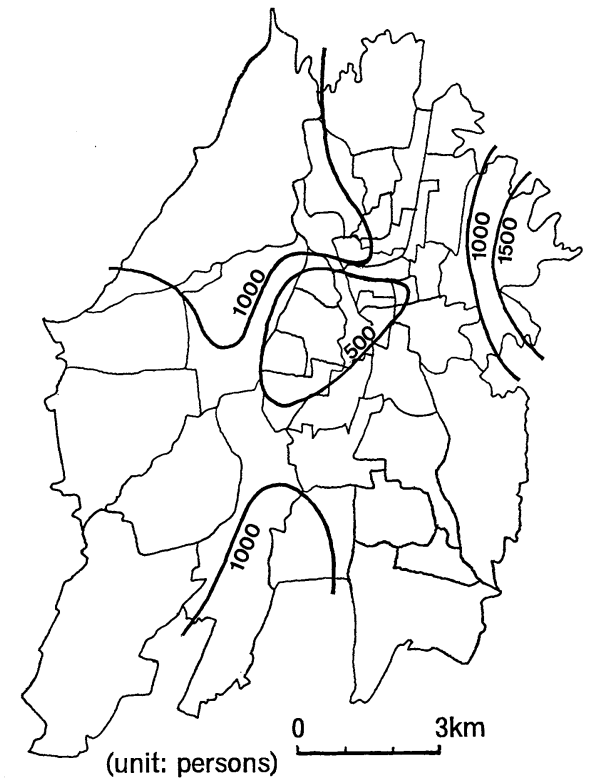

Fig. 2 Distribution of elderly population in 1992

figure is equal to the sum of the interactions $\left(\sum_{i} \sum_{j} S_{i j}\right.$ and $\left.\sum_{i} \sum_{k} S_{i k}\right)$ at both levels. In the study area, the central business district (CBD) is located around regions No. 10, 12 and 14 where elderly population is small, while the elderly population is large in the urban fringe (Fig. 2). Especially, regions No. 26, 34, 37, and 40 have a large number of the elderly population so that the number of the elderly people at each region is not normally distributed from the CBD outwards.

Here, it was assumed that travel costs $\left(c_{i j}\right.$ and $c_{\boldsymbol{i} \boldsymbol{k}}$ ) in equation (6) were identical to distances $\left(d_{i j}\right.$ and $\left.d_{i k}\right)$ in equations (7) and (8). Since public transportation dominates daily activities of pensioners, time distance was utilized as measures of the travel costs $\left(c_{i j}\right.$ and $\left.c_{i k}\right)$ and distances $\left(d_{i j}\right.$ and $d_{i k}$ ) (Herbert and Peace, 1980 ; Smith, 1984). Time distances were measured between centroids at each region using a bus time table in Matsumoto so as to minimize the objective function in equation (6) in a network ${ }^{6}$. Besides, a distance within the same region was measured by one-half time distance from a centroid to the nearest one $\mathrm{e}^{\text {7). }}$

The objective function in equation (6) was minimized along two scenarios. In Scenario 1, optimal locations were searched in a simple way: locations of short stay homes at the high level were selected amongst locations of day service centres at the low level. This restrict on location selection is formulated as follows :

$$
L_{\text {High }} \subset L_{\text {Low }} \subset L_{\text {Demand }}
$$

where

$L_{\text {Demand }}:$ the set of demand points location, and $L_{\text {Demand }}=\left\{L_{1}, L_{2}, \cdots, L_{l}\right\}$

$L_{\text {Low }}$ : the set of facility locations at the low level, and $L_{\text {Low }}=\left\{L_{L 1}, L_{L 2}, \cdots, L_{L m}\right\}$

$L_{H i g h}$ : the set of facility locations at the hig hlevel, and $L_{H i g h}=\left\{L_{H 1}, L_{H 2}, \cdots, L_{H n}\right\}$ $(0<n \leq m \leq l \leq 40)$.

On the other hand, Scenario 2 is so called backup system (Daskin and Stern, 1981). In the backup system, locations of facilities at the low level disagree with those at the low level. For example, in emergency medical care sys. tem, the backup system avoids the overload on basic emergency centre system at the low level in a medical hierarchy by transferring their patients to advanced emergency centres at the high level. To the contrary, such transfer is virtually impossible if both centres are located at the same places. For the elderly care facilities, the backup system is also valuable because the short stay homes could accept senile elderly persons if day service centres were fully occupied. The backup system is expressed as :

$$
\begin{aligned}
& L_{\text {Low }} \subset L_{\text {Demand }} \\
& L_{\text {High }} \subset L_{\text {Demand }} \\
& L_{\text {Low }} \cap L_{\text {High }}=\phi
\end{aligned}
$$

where notations are identical in equation (11).

Finally, the objective function in equation 
(6) was solved through Teitz and Bart (1968) algorithm. According to Mirchandani and Reilly (1987, p. 204), this algorithm starts with a set of initial sites, and substitute a site within the current set for a site outside the current set one by one. If a site substitutions reduces the value of the objective function, then the new site is included and the old site is eliminated from the current set. This procedure continues until no substitution yields decrease in the value of the objective function. Rushton and Kohler (1973) showed that this algorithm converges faster to an optimal solution and is more accurate than others, such as algorithm developed by Copper (1963) or by Maranzana (1964). Since Teitz and Bart algorithm is one of heuristic solutions, final solutions are not exact but good ones.

In short, location-allocation models specify the number of optimal locations under a set of constraints. In this study, the number of facilities is 14 at the fist level and five at the high level on the basis of an analogy from the central place theory where one central place at a high level encompasses three demand points at the lower level in the case of $K=3$.

\section{2) Measure of location pattern}

The nearest neighbour measure identifies location patterns of facilities at both the low and high levels by means of three categories : regular, random, and clustered patterns (Clark and Evans, 1954). The nearest neighbour measure $(R)$ is formulated as :

$$
R=:\left[1 / n \times\left(\sum_{i} r_{i j}\right)\right] /\left(1 / 2 D^{1 / 2}\right)
$$

where

$n:$ the number of facilities,

$r_{i j}$ : the nearest neighbour distance between, facilities $i$ and $j$,

$D$ : density of facilities, namely $D=n / a$ (here $a$ indicates area).

The range of this measure is between null and
2.149. If the value is null, all points are clustered around a point. Conversely, points are regularly distributed if the measure has the maximum value. Points are randomly distributed if the measure is equal to one. Amongst the three patterns, only random pattern can be statistically tested through examining whether facility locations are fitted to Poisson distribution. Thus, location patterns of facilities were identified by significant tests of $z$-value ${ }^{8)}$. Those tests detect significant difference in facility locations from random distribution.

In the following section, results of applications of the hierarchical generalized $p$-median problem are presented under variation in the distance-decay parameter at both the low and high levels.

\section{Results}

Results of the applications of the hierarchical generalized $p$-median problem are presented in the following three subsections. In the first subsection, we describe findings derived from the analysis at the low level of the hierarchical generalized $p$-median model in three different cases of the distance-decay parameter. In the second and third subsections, we show results at the high level along the two scenarios. In all the subsections, we examine some statistics of distance and population, locations of and populations allocated to facilities, and inflows to each facility.

1) Results of the applications of the hierarchical generalized $p$-median model at the low level

(1) Statistics of distance and population

For Table 1, total travel costs increase drastically with decrement in the distance-decay parameter ${ }^{9}$. Conversely, sums of distance and mean distances decline with the decreasing number of the distance-decay parameter ${ }^{10}$. O'Kelly 
Table 1 Statistics of distance and population at the low level

\begin{tabular}{lcrrrrr}
\hline & Total travel costs & \multicolumn{3}{c}{ Distance } & \multicolumn{2}{c}{ Population } \\
\cline { 3 - 5 } cares $\left(\beta_{L}\right)$ & $\left(Z_{L}\right)$ & Sum & Mean & $S D$ & $S D$ \\
\hline A $(1.5)$ & $92,174.29$ & $10,555.06$ & 18.85 & 9.73 & 181.78 \\
B $(0.15)$ & $240,070.49$ & $10,062.76$ & 17.97 & 9.94 & 63.57 \\
C $(0.015)$ & $354,245.58$ & $7,439.42$ & 13.29 & 7.78 & 18.74 \\
\hline
\end{tabular}

The distance and population units are minutes and persons, respectively.

SD denotes the standard deviation.

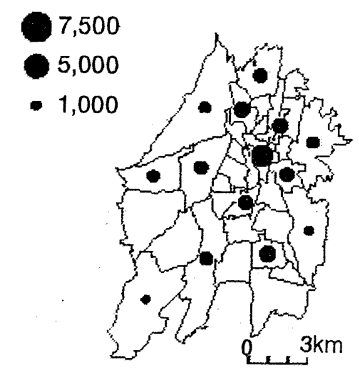

A

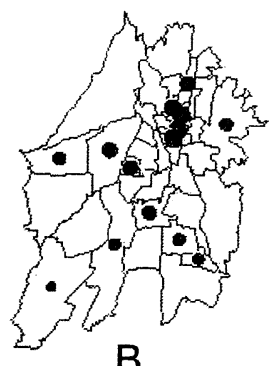

B

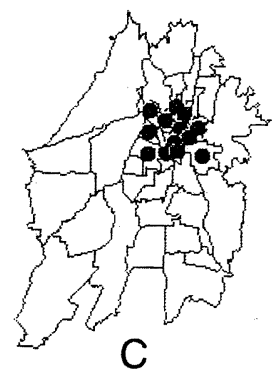

Fig. 3 Locations of facilities and allocated population at the low level

and Storbeck (1984, p. 124) obtained the same results in terms of distance. They argued that if inaccessibility to the nearest centre is high then the second nearest centre should be located in the vicinity of the first one. Their argu- ment suggests that facilities are centralized in the centre of a study area when distance-decay effects are weak.

The standard deviation of population diminishes with decrement in the distance-decay parameter ${ }^{11}$. This indicates that population is more evenly allocated to facilities as effects of friction of distance become weak.

(2) Locations of and population allocation to 14 facilities

Figure 3 clearly displays a contrast of the location pattern resulted from difference in the distance-decay parameter. In Case A, locations of facilities exhibit decentralized distribution by strong distance-decay effects, while centralized one by weak distance impedance in Case C. O'Kelly (1987, p. 317) obtained the same results as the present study. He showed that facilities are clustered in the centre of his study area, when the distance-decay parameter is small. On the other hand, facilities are decentralized in his location-allocation study with a large distance-decay parameter like a deterministic location-allocation model. As a result, Case $\mathrm{B}$ demonstrates an intermediate location pattern between Cases $A$ and $C$. In Case B, facilities are randomly distributed and make three circles around regions No. 10, 32, and 37. Yamashita (1993) found out an identical random distribution of facilities in a probabilistic location-allocation model with the distance-decay parameter of 0.15 , though re- 
Table 2 Nearest neighbour measure $(R)$ at the low level

\begin{tabular}{cccc}
\hline \hline case & $\mathrm{A}$ & $\mathrm{B}$ & $\mathrm{C}$ \\
\hline$R$ & $1.61^{* *}$ & 1.03 & $0.48^{* *}$ \\
\hline$* *$ significant at & 0.01 & level of confidence.
\end{tabular}

gional population is normally distributed over the study area in his research.

The nearest neighbour measures evidently detect the three location patterns (Table 2). The nearest neighbour measure is approximately 1.6 and significant at 0.01 level of confidence in Case $\mathrm{A}$ so that the 14 facilities are regularly located. In Case $B$, facilities are randomly distributed because the measure has almost one. Conversely, the measure is larger than null and less than one and significant at 0.01 level of confidence in Case C. This indicates that 14 facilities are clustered around the centre of the study area.

As to population allocation, variation in population between facilities apparently reduces with decrement in the distance-decay parameter. In Cases A and B, large population is allocated to some facilities. To the contrary, population is almost evenly assigned to 14 facilities in Case $\mathrm{C}$ because pensioners could access to all the facilities by weak effects of friction of distance.

(3) Inflows to the 14 facilities

Population in each region comes to be more evenly allocated to facilities as distance impedance becomes weak (Fig. 4). Apparently, population is allocated to the nearest facilities in Case A. In this case, allocation pattern is much similar to that of deterministic locationallocation models so that these models are regarded as one of variations of the probabilistic ones. In Case B, population in each region is allocated to some facilities because the nearest allocation rule is alleviated. In Case $\mathrm{C}$,
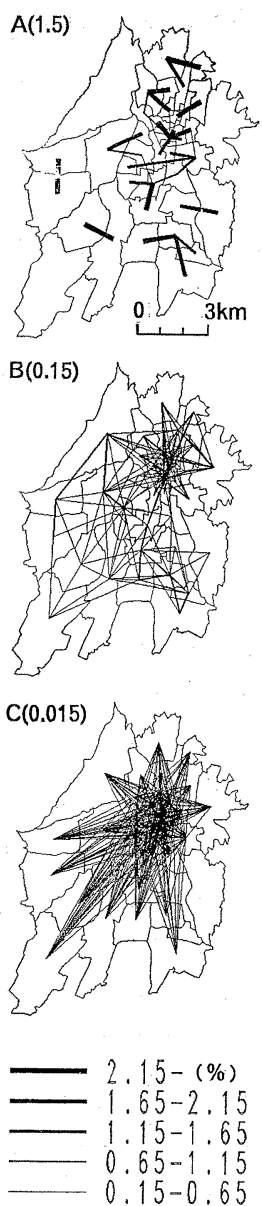

Fig. 4 Inflows to each facility at the low level The lines indicate percentage of the number of elderly people in the total elderly population

Top: population at each facility location is allocated to its own facility.

Bottom: population at each region is allocated to all 14 facilities, though some inflows are omitted in this figure because they do not exceed 0.15 percent of the total population.

population in each region is assigned to all facilities owing to almost no distance-decay effects.

2) Results of the applications of the hierarchical generalized $p$-median model at the high level (Scenario 1)

(1) Statistics of distance and population 
Table 3 Statistics of distance and population at the high level in Scenario 1

\begin{tabular}{|c|c|c|c|c|c|c|}
\hline \multirow{2}{*}{$\operatorname{cases}\left(\beta_{L}, \beta_{H}\right)$} & \multicolumn{2}{|c|}{ Total travel costs } & \multicolumn{3}{|c|}{ Distance } & \multirow{2}{*}{$\frac{\text { Population }}{S D}$} \\
\hline & $\left(Z_{L}+Z_{H}\right)$ & $\left(Z_{H}\right)$ & Sum & Mean & $S D$ & \\
\hline $\mathrm{A}_{1}(1.5,1.5)$ & $261,577.23$ & $169,402.94$ & $3,433.74$ & 17.17 & 9.22 & 274.93 \\
\hline $\mathrm{A}_{2}(1.5,0.15)$ & $343,984.46$ & $251,810.17$ & $3,582.63$ & 17.91 & 9.33 & 166.45 \\
\hline $\mathrm{A}_{3}(1.5,0.015)$ & $469,429.48$ & $377,255.19$ & $2,847.69$ & 14.24 & 8.23 & 52.99 \\
\hline $\mathrm{B}_{2}(0.15,0.15)$ & $491,638.15$ & $251,567.66$ & $3,731.09$ & 18.66 & 10.87 & 160.20 \\
\hline $\mathrm{B}_{3}(0.15,0.015)$ & $602,056.21$ & $361,985.72$ & $2,730.93$ & 13.66 & 8.59 & 52.48 \\
\hline $\mathrm{C}_{3}(0.015,0.015)$ & $696,087.96$ & $241,842.38$ & $2,501.30$ & 12.51 & 8.10 & 51.92 \\
\hline
\end{tabular}

The distance and population untis are minutes and persons, respectively.

$\mathrm{SD}$ denotes the standard deviation.

Except for sum of distance and mean distance, fluctuation in statistics of distance at the high level is much similar to that at the low level (Table 3). The total travel costs at the high level $\left(Z_{H}\right)$ increase with decrement in the distance-decay parameter in the same groups derived from the same locations of facilities at the low level. Conversely, the sum of distance and mean distances do not gradually decrease, as distance impedance declines. Unlike at the low level, O'Kelly and Storbeck's (1984) argument on distance was not supported in Scenario 1. In fact, Case $\mathrm{A}_{2}$ has the largest values of both sum of distance and mean distance in Cases $A_{1}, A_{2}$ and $A_{3}$ so that the location patterns of 14 facilities at the low level did not cause monotonous decline in sum of distance and mean distance in Cases $\mathrm{A}_{1}, \mathrm{~A}_{2}$, and $\mathrm{A}_{3}$. Only sustainable argument by $\mathrm{O}$ 'Kelly and Storbeck (1984) is that strong distancedecay effects, namely 1.5 and 0.15 , bring long mean distances between facilities while weak effects, namely 0.015 , result in short mean distance in these cases. Thus, we could expect decentralized distribution in the strong distance decay effects and centralized one in the weak effects.

The influence of location patterns at the low level could be observed in sum of total travel costs $\left(Z_{H}\right)$. While Case $\mathrm{A}_{1}$ has the minimum value, Case $A_{3}$ has the maximum value, though we may expect that Case $C_{3}$ has the maximum value from the findings of the total travel costs at the low level.

Fluctuation in standard deviation of population at the high level is much similar to that at the low level. Population in each region is more evenly allocated to five facilities with decrement in the distance-decay parameter. Case $A_{1}$ has the largest value of the standard deviation, while Case $\mathrm{C}_{3}$ has the smallest.

Consequently, Case $A_{1}$ is considered as the optimal locations from the findings on the smallest sum of total travel costs $\left(Z_{L}+Z_{H}\right)$ in Scenario 1 . To the contrary, Case $\mathrm{C}_{3}$ might be regarded as equality-oriented locations in the hierarchical generalized $p$-median problem from the observation on the smallest value of the standard deviation of distance in the six cases.

(2) Locations of and population allocation to five facilities

In Fig. 5, we find distinctive location patterns emerged from variation in the distance-decay effects. Like at the low level, location patterns at the high level change from decentralized to centralized distributions in the same Cases with decreasing degree of distance impedance. Nearest neighbour measures disclose a differ- 


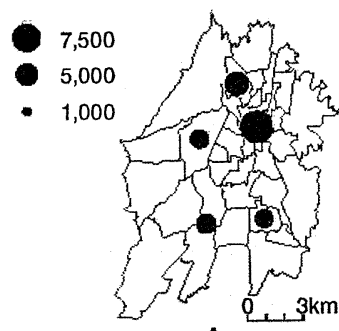

$\mathrm{A}_{1}$

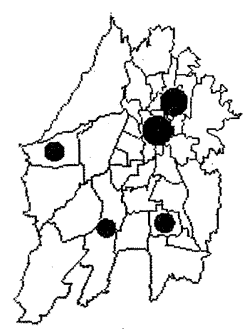

$\mathrm{A}_{2}$

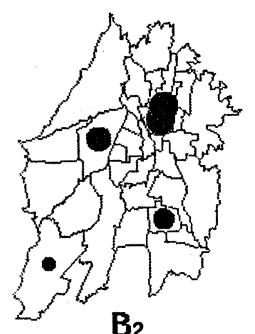

$\mathrm{B}_{2}$

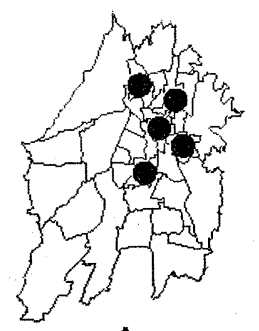

A3

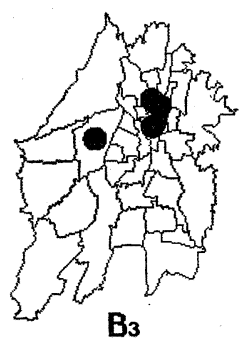

$\mathrm{B}_{3}$

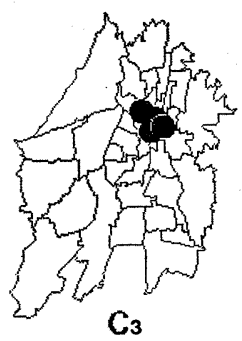

Fig. 5 Locations of facilities and allocated population at the high level in Scenario 1

Table 4 Nearest neighbour measure $(R)$ at the high level in Scenario 1

\begin{tabular}{lccc}
\hline \hline & \multicolumn{3}{c}{$\beta$ at the high level } \\
\cline { 2 - 4 } & 1.500 & 0.150 & 0.015 \\
\hline $\begin{array}{l}\beta \text { at the } \\
\text { low level. }\end{array}$ & & & \\
1.500 & $\mathrm{~A}_{1}(1.27)$ & $\mathrm{A}_{2}(1.39)$ & $\mathrm{A}_{3}(0.85)$ \\
0.150 & & $\mathrm{~B}_{2}\left(1.49^{*}\right)$ & $\mathrm{B}_{3}\left(0.38^{* *}\right)$ \\
0.015 & & & $\mathrm{C}_{3}\left(0.16^{* *}\right)$ \\
\hline
\end{tabular}

** significant at 0.01 level of confidence.

* significant at 0.05 level of confidence.

ence in locational configuration between the decentralize and centralize patterns (Table 4). The nearest neighbour measure shows that location pattern of the five facilities in Cases $B_{2}$ is regular clistribution. Besides, in Cases $A_{1}, A_{2}$ and $A_{3}$, nearest neighbour measures are almost one so that distribution of five facilities are identified as random patterns. Conversely, locational configurations of facilities in Cases $\mathrm{B}_{3}$ and $\mathrm{C}_{3}$ are classified as clustered patterns because nearest neighbour measures have low values very much and are significant at 0.01 level of confidence. Unlike in the low level, both the large value and the small value of the distancedecay parameter brought random distribution in Cases $A_{1}$ and $A_{3}$ in the high level. It is worth noting that the medium value of distance-decay parameter leads to a regular distribution in Case $B_{2}$. Those phenomena may suggest that that the location patterns at the low level affect those at the high level.

Like the low level, variation in population allocated to five facilities reduces with declining 


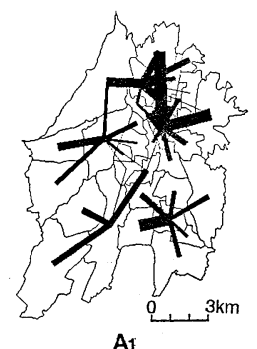

A1

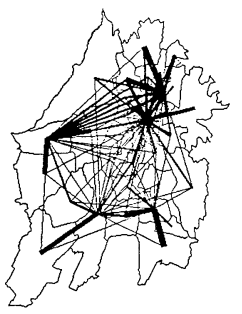

A2

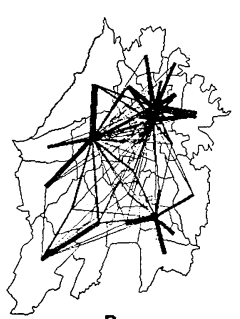

$\mathrm{B}_{2}$

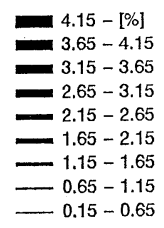

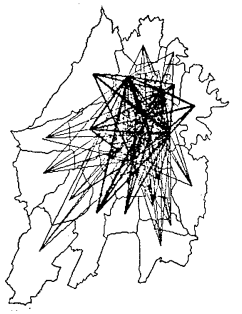

A3

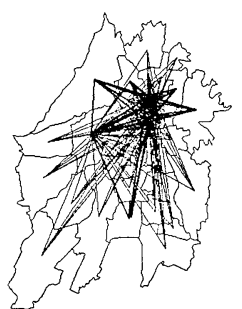

$\mathrm{B} 3$

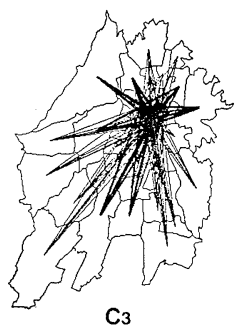

Fig. 6 Inflows to each facility at the high level in Scenario 1 The lines indicate percentage of the number of elderly people in the total elderly population.

From top left to bottom right: population at each facility location is allocated to its own facility.

effects of the distance impedance at the high level. For Cases $A_{1}, A_{2}$ and $B_{2}$, a large number of population are assigned to specific facilities. Conversely, population is evenly allocated to all the five facilities in the other cases.

(3) Inflows to the five facilities

Like at the low level, population is more evenly allocated to all facilities at the high level with decrement in the distance-decay parameter (Fig. 6). In Case $A_{1}$, population is chiefly assigned to nearest facilities. With decreasing effects of friction of distance, the nearest allocation rule is relaxed so that population in each region is assigned to some facilities at the high level in Cases $A_{2}$ and $B_{2}$. In
Cases $A_{s}, B_{3}$ and $C_{3}$, pensioners can access to farthest facilities regardless of distance impedance.

3) Results of the applications of the hierarchical generalized $p$-median model at the high level (Scenario 2)

(1) Statistics of distance and population

Fluctuation in statistics of distance at the high level is much similar to that at the low level (Table 5). The total travel costs at the high level $\left(Z_{H}\right)$ increase with decrement in the distance-decay parameter in the same groups derived from the same locations of facilities at the low level. Unlike in Scenario 1, the sum of distance and mean distances gradually de- 
Table 5 Statistics of distance and population at the high level in Scenario 2

\begin{tabular}{|c|c|c|c|c|c|c|}
\hline \multirow{2}{*}{$\operatorname{cases}\left(\beta_{L}, \beta_{H}\right)$} & \multicolumn{2}{|c|}{ Total travel costs } & \multicolumn{3}{|c|}{ Distance } & \multirow{2}{*}{$\frac{\text { Population }}{S D}$} \\
\hline & $\left(Z_{L}+Z_{H}\right)$ & $\left(Z_{H}\right)$ & Sum & Mean & $S D$ & \\
\hline $\mathrm{A}_{1}^{\prime}(1.5,1.5)$ & $263,372.38$ & $171,198.09$ & $3,381.41$ & 16.91 & 8.67 & 285.25 \\
\hline $\mathrm{A}_{2}^{\prime}(1.5,0.15)$ & $355,099.42$ & $262,925.13$ & $3,557.13$ & 17.79 & 10.09 & 150.91 \\
\hline $\mathrm{A}_{3^{\prime}}(1.5,0.015)$ & $438,432.07$ & $346,257.78$ & $2,536.80$ & 12.68 & 8.15 & 51.95 \\
\hline $\mathrm{B}_{2}^{\prime}(0.15,0.15)$ & $507,084.49$ & $267,014.00$ & $3,732.96$ & 18.67 & 10.28 & 158.39 \\
\hline $\mathrm{B}_{3}{ }^{\prime}(0.15,0.015)$ & $590,042.58$ & $349,972.09$ & $2,579.90$ & 12.90 & 8.12 & 52.06 \\
\hline $\mathrm{C}_{3^{\prime}}(0.015,0.015)$ & $750,243.55$ & $395,997.97$ & $3,017.35$ & 15.09 & 7.80 & 53.46 \\
\hline
\end{tabular}

The distance and population units are minutes and persons, respectively.

$S D$ denotes the standard deviation.

crease in Cases $\mathrm{A}_{1}{ }^{\prime}, \mathrm{A}_{2}{ }^{\prime}$ and $\mathrm{A}_{3}{ }^{\prime}$ along with in Cases $\mathrm{B}_{2}{ }^{\prime}$ and $\mathrm{B}_{3}{ }^{\prime}$, as distance impedance declines in Scenario 2. As a result, Scenario 2 supports O'Kelly and Storbeck's (1984) argument on distance. When we searched the optimal locations of five facilities at the high level in Scenario 2, we took no account of locations of 14 facilities at the low level. The ignorance of locations of the 14 facilities at the low level also leads to monotonous decline in the mean distance. Since the mean distances declines monotonously, we could expect decentralized distribution in the strong distance-decay effects and centralized one in the weak effects. Consequently, the total travel costs $\left(Z_{L}+Z_{H}\right)$ in Case $A_{1}{ }^{\prime}$ is the minimum, while in Case $\mathrm{C}_{3}{ }^{\prime}$ being the maximum, as we expected.

Fluctuation in standard deviation of population at the high level in Scenario 2 is much similar to that at the low level. Population in each region is more evenly allocated to five facilities with decrement in the distance-decay parameter. In fact, Case $\mathrm{A}_{1}{ }^{\prime}$ has the highest value of the standard deviation of population, while Case $\mathrm{C}_{3}{ }^{\prime}$ has the lowest.

As a result, Case $\mathrm{A}_{1}{ }^{\prime}$ is considered as the optimal locations in Scenario 2 owing to the smallest sum of total travel costs.

(2) Locations of and population allocation to five facilities

For Fig. 7, we find two locational pattern of five facilities at the high level. One is the random distribution in Cases $\mathrm{A}_{1}{ }^{\prime}, \mathrm{A}_{2}{ }^{\prime}, \mathrm{B}_{2}{ }^{\prime}$ and $\mathrm{C}_{3}{ }^{\prime}$, and the other is the clustered distribution in Cases $\mathrm{A}_{3}{ }^{\prime}$ and $\mathrm{B}_{3}{ }^{\prime}$. Unlike in Scenario 1, Case $\mathrm{C}_{3}{ }^{\prime}$ exhibits the random distribution in Scenario 2 regardless of the weakest distancedecay effects.

Nearest neighbour measures disclose a difference in locational configuration between the random and clustered patterns (Table 6). Only Cases $\mathrm{A}_{3}{ }^{\prime}$ and $\mathrm{B}_{3}{ }^{\prime}$ are significantly distinguished from the random distribution. Although two types of location patterns, namely random and clustered patterns, are observed at the high level, the largest value of distance-decay parameter does not bring a regular distribution in Case $\mathrm{A}_{1}{ }^{\prime}$. Since locations of 14 facilities at the low level are intended to disagree with five facilities at the high level in Scenario 2, and since the 14 facilities in Case A is regularly distributed at the low level, five facilities in Case $A_{1}{ }^{\prime}$ might not be scattered over the study area at the high level. This is also the reason that Case $\mathrm{A}_{1}{ }^{\prime}$ is identified as the random pattern.

Like in Scenario 1, standard deviation of population decreases with decline in the dis- 


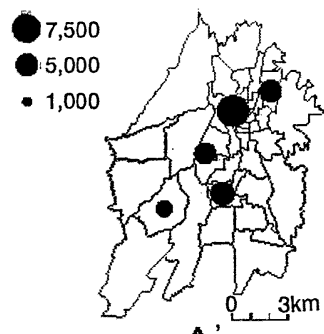

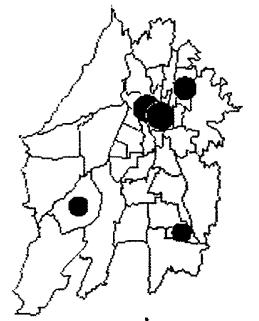

$A_{2}$

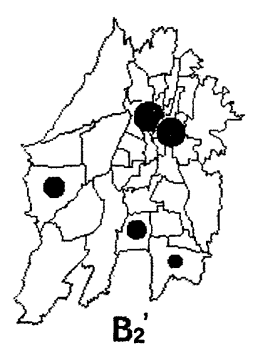

$\mathrm{B}_{2}{ }^{\prime}$

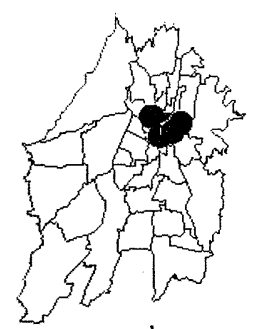

$\mathrm{A}_{3}$

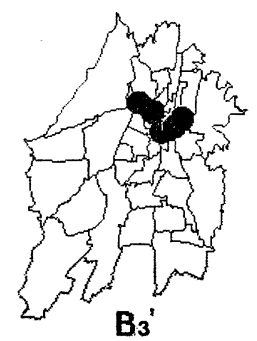

$\mathrm{B}_{3}$

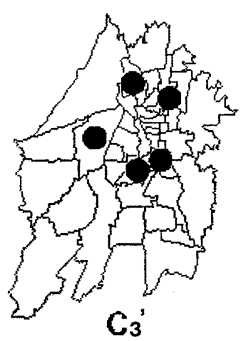

Fig. 7 Locations of facilities and allocated population at the high level in Scenario 2

Table 6 Nearest neighbour measure $(R)$ at the high level in Scenario 2

\begin{tabular}{lccc}
\hline \hline & \multicolumn{3}{c}{$\beta$ at the high level } \\
\cline { 2 - 4 } & 1.500 & 0.150 & 0.015 \\
\hline $\begin{array}{l}\beta \text { at the } \\
\text { low level } \\
1.500\end{array} \mathrm{~A}_{1}{ }^{\prime}(1.43)$ & $\mathrm{A}_{2}{ }^{\prime}(1.32)$ & $\mathrm{A}_{3}{ }^{\prime}\left(0.15^{* *}\right)$ \\
0.150 & & $\mathrm{~B}_{2}^{\prime}(1.01)$ & $\mathrm{B}_{3}{ }^{\prime}\left(0.23^{* *}\right)$ \\
0.015 & & & $\mathrm{C}_{3}{ }^{\prime}(1.06)$ \\
\hline
\end{tabular}

** significant at 0.01 level of confidence.

* significant at 0.05 level of confidence.

tance-decay effects in Scenario 2. In Cases $\mathrm{A}_{1}{ }^{\prime}, \mathrm{A}_{2}{ }^{\prime}$ and $\mathrm{B}_{1}{ }^{\prime}$, variation in population allocated to five facilities is large. Conversely, population is evenly assigned to five facilities in Cases $\mathrm{A}_{3}{ }^{\prime}, \mathrm{B}_{3}{ }^{\prime}$ and $\mathrm{C}_{3}{ }^{\prime}$.
(3) Inflows to the five facilities

Like in Scenario 1, population is evenly allocated to all facilities with decrement in the distance-decay parameter in Scenario 2 (Fig. 8). In Cases $\mathrm{A}_{1}{ }^{\prime}, \mathrm{A}_{2}{ }^{\prime}$ and $\mathrm{B}_{2}{ }^{\prime}$, population is chiefly assigned to nearest facilities. In Cases $\mathrm{A}_{3}{ }^{\prime}, \mathrm{C}_{2}{ }^{\prime}$ and $\mathrm{C}_{3}{ }^{\prime}$, pensioners can access to all facilities regardless of distance impedance.

(4) Comparison of Scenario 1 with Scenario 2 Here, we compare statistics of distance and population at the high level between Case $A_{1}$ in Scenarios 1 and Case $A_{1}{ }^{\prime}$ in Scenario 2 (see also, Tables 3 and 5). Findings are noteworthy at three points. First, the sum of the total travel costs $\left(Z_{L}+Z_{H}\right)$ in Case $A_{1}$ are smaller than those in Case $\mathrm{A}_{1}{ }^{\prime}$. It is, therefore, 

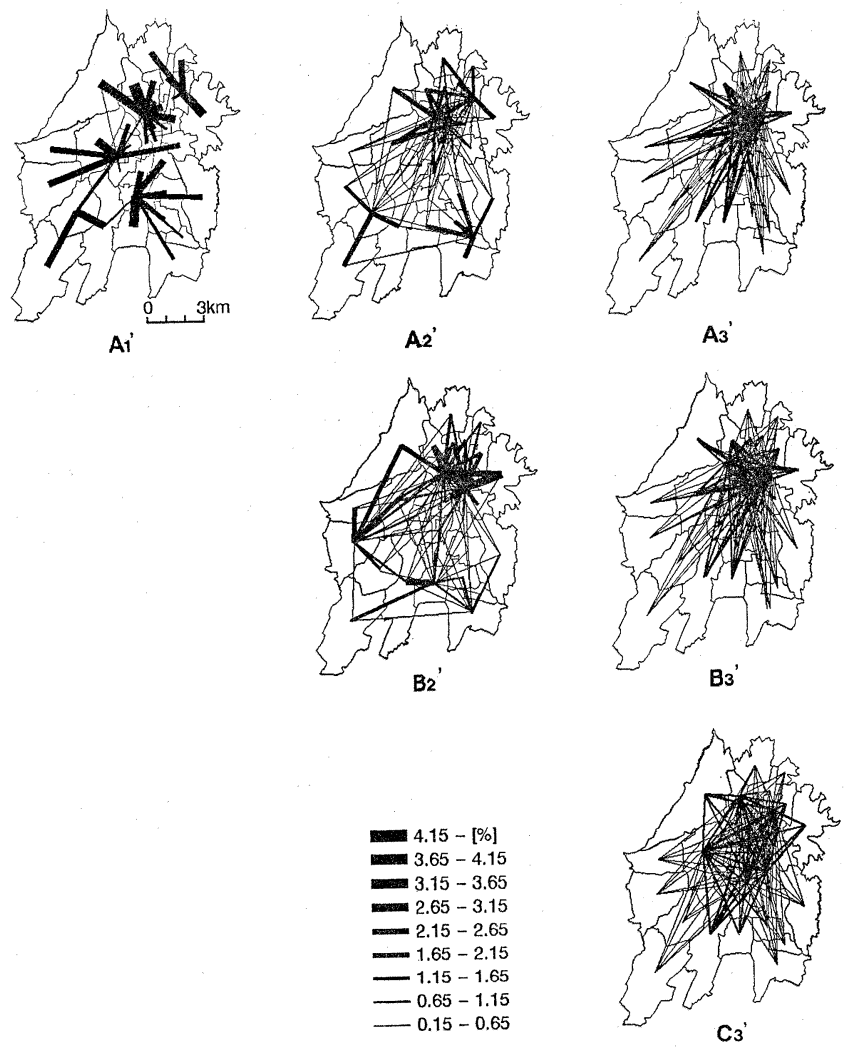

Fig. 8 Inflows to each facility at the high level in Scenario 2 The lines indicate percentage of the number of elderly people in the total elderly population.

From top left to bottom right : population at each facility location is allocated to its own facility.

concluded that Case $A_{1}$ is the optimal locations of the hierarchical generalized $p$-median problem of the facilities for senile people, while Case $\mathrm{A}_{1}{ }^{\prime}$ is considered as an alternative. Second, the backup system of Case $\mathrm{A}_{1}{ }^{\prime}$ brings more disperse facility locations than the facility locations in Case $A_{1}$. The larger nearest neighbour measure in Case $A_{1}{ }^{\prime}$ than Case $A_{1}$ confirms the disperse locations in Case $A_{1}{ }^{\prime}$ (see Tables 4 and 6). The disperse locations in Case $A_{1}{ }^{\prime}$ also cause smaller values of the mean distance and the standard deviation of distances in Case $A_{1}^{\prime}$ than Case $A_{1}$. Finally, population is more evenly allocated to five centres in Case $A_{1}$ than Case $A_{1}{ }^{\prime}$. The smaller value of the standard deviation of population shows the even allocations in Case $A_{1}$ than Case $\mathrm{A}_{1}{ }^{\prime}$.

\section{Discussion}

In this section, the optimal locations of day service centres and short stay homes in Case $A_{1}$ are compared with those of the existing facilities. As an alternative, facility locations in Case $\mathrm{A}_{1}{ }^{\prime}$ are also compared with those of the existing facilities.

Figure 9 shows locations of both existing day service centre and short stay homes in 1992. Apparently, there are a small number of facilities for senile people in Mastumoto. 


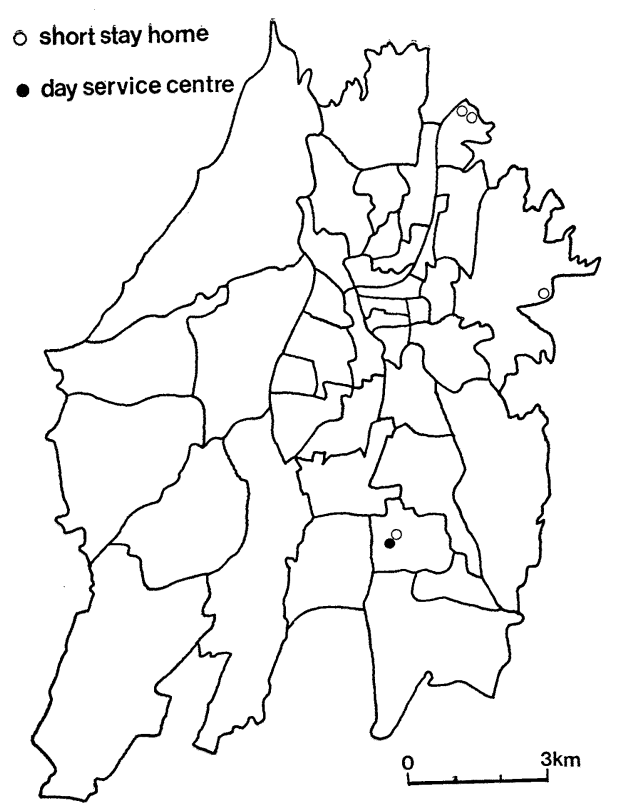

Fig. 9 Locations of existing day service centre and short stay home

Regrading the number of day service centres and short stay homes, the Welfare Ministry draws a guideline for municipalities to establish eight day service centres for each 100,000 population and to equip with four beds at a short stay home for each 10,000 population. In accordance with this guideline, Matsumoto will have at least 16 day service centres and two short stay homes in $1999^{12}$.

Both the locations of the existing day service centre and the short stay homes differ from those of Cases $\mathrm{A}_{1}$ and $\mathrm{A}_{1}{ }^{\prime}$ (see also, the Figs. 3,5 and 7). Only the day service centre and the short stay home in region No. 29 are fitted to those of Case $A_{1}$. The existing short stay homes are located in the urban fringe of Matsumoto, while no facility is found in the central area of the city. A report on utilization of day service centres confirms the fact that the remote locations of day service centres in the urban fringe compel senile persons and their caretakers to travel long. This report shows that average distance access to a day service centre is 18.7 kilometre and average travel time to it is 64.8 minutes $^{13)}$. On the basis of the optimal locations of $A_{1}$ and also of $\mathrm{A}_{1}{ }^{\prime}$, the newly-constructed facilities, especially day service centres, should be established in the central area of the city.

We may consider two reasons for the remote locations of day service centres and short stay homes. The one, also the most crucial reason, is high land prices in Japan which force elderly care facilities to be located in the urban fringe. The other is also related to an image of the elderly care facility. The elderly care facilities, especially nursing homes for the aged, to which the day service cenrtes and the short stay homes are attached, are regarded as kind of noxious facility like waste-processing or sewage-purification facilities (Dear and Wittman, 1980). The fact that both the day service centres and short stay home acommodate physically and mentally senile persons overlaps with mental hospital. This may imagine the day service centres and short stay homes as a noxious facility. Consequently, the image may push the elderly facilities to the fringe of the city.

\section{Conclusion}

In this study, optimal locations of two types of facilities for the mental and physical senile persons were searched using the hierarchical generalized $p$-median model under variation in the distance-decay parameter: day service centres at the low level and short stay homes at the high level of the elderly care hierarchy. Two scenarios were examined in terms of facility locations. Locations of five short stay homes were selected amongst those of 14 locations of day service centres in Scenario 1, while being chosen amongst other places ex- 
luding locations of 14 day service centres in Scenario 2.

In Scenario 1, Case $A_{1}$ had the minimum value of the total travel costs. In this case, the distance-decay parameter had the largest value at both the low and high levels. Thus, the locations derived from Case $A_{1}$, was considered as the optimal locations in Scenario 1. In Case $A_{1}$, regional population was allocated to the nearest facilities so that the allocated population to each facility varied from one to another. Besides, in this case, the 14 day service centres were regularly distributed, while the five short stay homes at the high level were randomly distributed.

Results of Scenario 2 was much similar to those of Scenario 1. Like Case $A_{1}$, Case $A_{1}{ }^{\prime}$ had the minimum value of the total travel costs so that facility locations derived from Case $A_{1}{ }^{\prime}$ was regarded as the optimal locations in Scenario 2. Besides, regional population was allocated to the nearest facilities in Case $\mathrm{A}_{1}{ }^{\prime}$. I)istribution of the 14 day service centres exhibited regular pattern, while that of the five short stay homes showed random pattern.

Compared Cases $A_{1}$ with Case $A_{1}{ }^{\prime}$, we found the total travel costs of Case $A_{1}$ was smaller than those of Case $\mathrm{A}_{1}{ }^{\prime}$. This draws, therefore, a conclusion that the facility locations derived from Case $A_{1}$ was the optimal locations in this study. It is, however, worth noting that the mean distance at the high level in Case $A_{1}{ }^{\prime}$ was shorter than that in Case $A_{1}$, and that the nearest neighbour measure of Case $\mathrm{A}_{1}{ }^{\prime}$ was larger than that of Case $A_{1}$. This indicated that differences in facility locations at the low and high levels in Case $\mathrm{A}_{1}{ }^{\prime}$ brought more scattered distribution of facilities at the high level than in Case $A_{1}$.

We found a large disagreement between the locations of the existing day service centres and short stay homes, and those of Cases $A_{1}$ and $\mathrm{A}_{1}{ }^{\prime}$. Especially, no facilities were estab. lished in the central area of Matumoto, while some facilities were expected to be located in this area in Cases $A_{1}$ and $A_{1}{ }^{\prime}$. The high land price and the image of the facilities for senile parsons as noxious facilities could force day service centres and short stay home to be located in the fringe of Matsumoto.

Although the optimal locations of day service centres and short stay homes were searched through the minimizing total travel costs, we should take account of other determinants, such as construction costs, running costs including personnel expenditure, in the $p$-median model. Besides, optical locations of facilities for the senile person could be found through equalityoriented location criteria, such as through maximizing consumers' benefit, minimizing variation in distance, maximum coverage of users. Thereby, further investigations on optimal locations of facilities for senile person shouold carry out from other perspectives.

\section{Acknowledgements}

The author would like to thank Dr. Satoru Itoh at Kanazawa University, Dr. Yuji Murayama at the University of Tsukuba, and anonymous referees for their valuable suggestions and comments on early drafts of this paper.

\section{Notes}

1) Church and Eaton (1987) reviewed hierarchical deterministic location-allocation models.

2) In this paper, the term, probabilistic allocation, is defined as the stochastic allocations enabling us to assign regional population to not only the nearest facility but also others. This term also juxtaposes the nearest-centre allocation.

3) Wilson (1978, p. 153) also gave a theoretical insight to incorporation of the central place theory into hierarchical probabilistic location-allocation models by introduction of a binary variable. 
4) Williams et al. (1990) tackled a probabilistic location-allocation problem with both mass and distance-decay parameters in their simulation study.

5) Matsumoto municipality (1992): Population in Matsumoto 1992 (Matsumoto shi (1992): Matsumoto shi no jinkoh) was employed.

6) The author utilized a bus time table of Matsumoto Electric Train Co. Ltd. (Matsumoto Denki Tetsudo Kabushiki Gaisha) in September, 1992.

7) Because there is no acceptable measure of distance within the same region, one-half distance was employed here.

8) $z$-value is formulated as :

$z=\left\{\left[1 /\left(n \times \sum_{i} r_{i j}\right)\right]-\left[1 / 2 D^{1 / 2}\right]\right\} /\left[0.261 /(n \times D)^{1 / 2}\right]$

9) The total travel costs at the low level in Table 1 are written as :

The total travel costs $\left(Z_{L}\right)=\sum_{i} \sum_{j} S_{i j} c_{i j}$ where,

$S_{i j}$ : interaction between regions $i$ and $j$,

$c_{i j}$ : distance between regions $i$ and $j$.

In the same fashion, the total travel costs at the high level in Tables 3 and 5 are expressed as : The total travel costs $\left(Z_{H}\right)=\sum_{i} \sum_{k} S_{i k} c_{i k}$ (18) where,

$S_{i k}$ : interaction between regions $i$ and $k$, $c_{i k}$ : distance between regions $i$ and $k$.

10) The sum of distance, the mean distance and the standard deviation of distance at the low level are measured by the following equations:

the sum of distance $=\sum_{i} \sum_{j} d_{i j}$

the mean distance $\left(\hat{d}_{i j}\right)=\sum_{i} \sum_{j} d_{i j} /(l \times m)$ (20)

the standard deviation of distance

$$
=\left[\sum_{i} \sum_{j}\left(d_{i j}-\hat{d}_{i j}\right)^{2} /(l \times m)\right]^{1 / 2}
$$

where

$d_{i j}$ : distance from region $i$ to facility $j$,

$l$ : the number of regions, namely $l$ is 40,

$m$ : the number of facilitie at the first level, namely $m$ is 14 .

In the same fashion, those measures at the high level are expressed as follows :

the sum of distance $=\sum_{i} \sum_{k} d_{i k}$

the mean distance $\left(\hat{d}_{i k}\right)=\sum_{i} \sum_{k} d_{i k} /(l \times n)$ (23)

the standard deviation of distance

$$
=\left[\sum_{i} \sum_{k}\left(d_{i k}-\hat{d}_{i k}\right)^{2} /(l \times n)\right]^{1 / 2}
$$

where,

$d_{i k}$ : distance from region $i$ to facility $k$,

$n$ : the number of facilities at the second level, namely $n$ is five.

11) Here, mean population and standard deviation of population at the low level are written as: Mean population $\left(\hat{S}_{i j}\right)=\left(\sum_{i} \sum_{j} S_{i j}\right) /(l \times m)$
Standard deviation of population

$$
=\left[\sum_{i} \sum_{j}\left(S_{i j}-\hat{S}_{\boldsymbol{i} j}\right)^{2} /(l \times m)\right]^{1 / 2}
$$

where

$S_{i j}$ : population assigned from region $i$ to facility $j$,

$l$ : the number of regions, namely $l$ is 40 ,

$m$ : the number of facilities at the first level, namely $m$ is 14 .

In the same fashion, mean population and standard deviation of population at the high level are expressed as :

Mean population $=\left(\sum_{i} \sum_{k} S_{i k}\right) /(l \times n)$

Standard deviation of population

$$
=\left[\sum_{i} \sum_{k}\left(S_{i k}-\hat{S}_{i k}\right)^{2} /(l \times n)\right]^{1 / 2}
$$

where

$S_{i k}$ : population assigned from region $j$ to facility $k$,

$n:$ the number of facilities at the second level, namely $n$ is five.

In sum, the mean population is 47.63 at the low level, while being 133.37 at the high level.

12) This plan to progress the elderly care is called "Gold plan". Since the total population in Matsumoto was just more than 200,000 and the average number of beds at a nursing home for the aged (yougo roujin houmu) is approximately 70 , at least two facilities were required for senile people in 1992, in case nursing homes for the aged would solitarily be utilized as short stay homes.

13) Those figures were derived from: Social Welfare Conference (1989): Report on day service centre 1990. Social welfare conference, Tokyo, 69 p. (Zenkoku Syakai Fukushi Kyougikai (1989): 1990 nen zenkoku dei saabisu sentaa jittai cyousa. Zenkoku syakai fukushi kyougikai, Tokyo, 69 p.).

\section{References}

Beaumont, J. R. (1980): Spatial interaction models and the location-allocation problem. J. Reg. Sci., 20, 37-50.

Church, R. L. and Eaton, D. J. (1987): Hierarchical location analysis using covering objectives. In Ghosh, A. and Rushton, G. eds.: Spatial anal$y$ sis and location-allocation models. Van Nostrand Reinhold, New York, 163-185.

Clark, P. J. and Evans, F. C. (1954): Distance to nearest neighbor as a measure of spatial relationships in population. Ecology, 35, 445-453.

Clark, W. A. V. (1968): Consumer travel patterns and the concept of range. Ann. Ass. Amer. Geogr., 52, 386-396. 
Clark, W. A. V. and Rushton, G. (1970): Models of intraurban consumer behavior and their implications for central place theory. Econ. Geogr., 46, 486-497.

Coelho, J. D. and Wilson, A. G. (1976): The optimal location and size of shopping centres. Reg. Stud., 10, 413-421.

Cooper, L. (1963): Location-allocation problems. Operat. Res., 11, 331-343.

Daskin, M. S. and Stern, E. H. (1981): Hierarchical objective set covering model for EMS vehicle deploymeat. Transport. Sci., 15, 137-152.

Dear, M. J. and Wittman, I. (1980): Conflict over the locetions of mental health facilities. In Herbert, D. T. and Johnston, R. J. eds. : Geography and the urban environment: Progress in research and application Vol. 3. Wiley, Chichester, 345362.

Fotheringham, A. S. and O'Kelly, M. E. (1989): Spatial interaction models: Formulations and applications. Kluwer Academic Publishers, Dordrecht, $224 \mathrm{p}$.

Herbert, D. T. and Peace, S. M. (1980): The elderly in an urban environment: A case study of Swansea. In Herbert, D. T. and Johnston, R. J. eds. : Geography and the urban environment: Prog. ress in research and application Vol. 3. Wiley, Chichester, 223-256.

Hodgson, M. J. (1978): Toward more realistic allocation in location-allocation models: An interaction approach. Environ. Plann. A, 10, 1273-1285.

Hodgson, M. J. (1981): A location-allocation model maximizing consumers' welfare. Reg. Stud., 15, 493-506.

Kohsaka, H. (1983): A central-place model as a two-level location-allocation system. Environ. $\mathrm{Pl}$ ann. $A, 15,5-14$.

Leonardi, G. (1981 a): A unifying framework for public facility location problems-Part 1: A critical overview and some unsolved problems. Environ. Plann. A, 13, 1001-1028.

Leonardi, G. (1981 b): A unifying framework for public facility location problems-Part 2: Some new models extensions. Environ. Plann. A, 13, 1085-1108.

Narula, S. C. (1984): Hierarchical location-allocation problems: A classification scheme. Euro. $J$. Operat. Res., 15, 93-99.

Maranzana, F. E. (1964): On the location of supply points to minimize transport costs. Operat. Res. Q., 15, 261-270.
Mirchandani, P. B. and Reilly, J. M. (1987): Spatial distribution design for fire fighting units. In Ghosh, A. and Rushton, G. eds. : Spatial analysis and location-allocation models. Van Nostrand Reinhold, New York, 186-223.

O'Kelly, M. E. (1987): Spatial interaction based location-allocation models. In Ghosh, A. and Rushton, G. eds. : Spatial analysis and location-allocation models. Van Nostrand Reinhold, New York, 302-326.

O'Kelly, M. E. and Storbeck, J. E. (1984) : Hierarchial location models with probabilistic allocation. Reg. Stud., 18, 121-129.

Rushton, G., Golledge, R. G. and Clark, W. A. V. (1967): Formulation and test of a normative model for the spatial allocation of grocery expenditures by a dispersed population. Ann. Ass. Amer. Geogr., 47, 389-400.

Rushton, G. and Kohler, J. A. (1973): ALLOCHeuristic solutions to multi-facility location problems on a graph. In Rushton, G., Goodchild, M. F. and Ostersh, L. M. eds.: Computer programs for location-allocation problems (monograph No. 6). Department of Geography, the University of Iowa, 163-187.

Smith, G. C. (1984): Spatial aspects of the shopping patterns of the urban elderly: The case of central area apartment dwellers. Can. J. Aging, 3, 133146.

Teitz, M. B. and Bart, P. (1968): Heuristic methods for estimating the generalized vertex median of a weighted graph. Operat. Res., 16, 955-961.

Williams, H. C. W. L., Kim, K. S. and Martin, D. (1990): Location-spatial interaction models: 1. benefit-maximizing configurations of services. Environ. Plann. A, 22, 1079-1089.

Wilson, A. G. (1978): Spatial interaction and settlement structure : Towards an explicit central place theory. In Karlqvist, A., Lundqvist, L. Snickars, F. and Weibull, J. W. eds. : Spatial interaction theory and planning models. North-Holland, Amsterdam, 137-156.

Wilson, A. G. and Senior, M. L. (1974): Some relationships between entropy maximizing models, mathematical programming models and their duals. J. Reg. Sci., 14, 207-215.

Yamashita, J. (1993): Effects of spatial interaction on spatial structure: A case of daycentre location in Malmö. Geogr. Rev. Japan, 66 B, 156-172.

(Received 10 February, 1994 ; Accepted 13 June, 1994) 
階層的一般化 $p$ メジアンモデルを用いた松本市における

高齢者施設の最適立地

山下潤*

本研究では, 精神的・肉体的に虚弱な老人のた めの施設である, デイサービスセンターと短期保 護施設の最適立地を求めた。デイサービスセンタ 一では，虚弱老人に対して，日中さまざまなサー ビスが提供されている。したがって, 介護者が虚 弱な高齢者を容易に輸送するため，デイサービス センターは虚弱老人の住居近くに立地することが 望ましい。短期保護施設では，一定期間，虚弱老 人に対してより高水準の社会サービスが施されて いる。デイサービスセンターと異なり, 短期保護 施設は虚弱老人の住居近くに立地する必要はない。 なぜなら, 虚弱老人は短期保護施設と住居との間 を毎日通ら必要がないからである。デイサービス センターと短期保護施設に対する需要における距 離弾性の違いを考慮できるので, デイサービスセ ンターと短期保護施設の最適立地を求める際に, 階層的一般化 $p$ メジアンモデルは適している。 この階層的一般化 $p$ メジアンモデルにおいて， 松本市の老年人口とネットワーク上の時間距離を 用いて，総輸送費用を最小化した。松本市におけ

\footnotetext{
* 筑波大学地球科学研究科
}

る老年人口率と自動車保有率が高いことが, 松本 市を研究対象地域に選定した理由である。階層的 一般化 $p$ メジアン問題を，2つのシナリオに沿 って解いた。シナリオ 1 では，14のデイサービス センターの立地点から 5 つの短期保護施設の立地 点を選択した。バックアップシステムと称される シナリオ 2 では，14のデイサービスセンターの立 地点以外の場所から 5 つの短期保護施設の立地点 を選択した。分析の結果, シナリオ 1 と 2 から得 られたデイサービスセンターの最適立地点は都市 内に分散して分布し, 短期保護施設の最適立地点 はランダムに分布している。これらの最適立地点 は，既存のデイサービスセンターや短期保護施設 の立地点と異なる。松本市において, デイサービ スセンターと短期保護施設が都市の中心部で少な いことが分かった。既存の施設が都市の周辺部に 立地しているので, 虚弱老人は長距離の移動を強 いられている。高い地価と有害施設としての虚弱 老人向け施設のイメージが, デイサービスセンタ 一と短期保護施設を都市の周辺部に立地させてい る理由であると考えられる。 